\title{
Effect of Using Stone Cutting Slurry Waste (Al-Khamkha) on the Compaction Characteristics of Jerash Cohesive Soil
}

\author{
Talal Masoud \\ Civil Engineering Department, College of Engineering, Jerash University, Jerash, Jordan \\ Email: dr.talalmasoud@outlook.com
}

Received 7 April 2015; accepted 1 June 2015; published 5 June 2015

Copyright (C) 2015 by author and Scientific Research Publishing Inc. This work is licensed under the Creative Commons Attribution International License (CC BY). http://creativecommons.org/licenses/by/4.0/ c) (i) Open Access

\section{Abstract}

The aim of this research is to study the effect of using (Al-KHAMKHA) is stone cutting slurry waste local name in JORDAN on the unit weight and moisture content of Jerash cohesive soil Al-Khamkha which is the local name of the stone cutting slurry waste which is produced during the cutting operation, This water carries large amounts of stone powder, which leads to complex nature of environmental problem so these waste material needs to be utilized meaningfully in economic way. The degree of compaction of a soil is measured in terms of its dry unit weight Al-Khamkha mixed with Jerash cohesive soil at different amount ranges from $0 \%, 5 \%, 10 \%, 15 \%$, up to $50 \%$ and compaction characteristics of Jerash cohesive soil without and with different amount of AlKhamkha was studied. This investigation show that as the amount of $\mathrm{Al}$-Khamkha increase from $0 \%$ to $15 \%$, the dry unit weight of Jerash cohesive soil increase from $14.4 \mathrm{KN} / \mathrm{m}^{3}$ at $0 \%$ of Al-Khamkha to $16.5 \mathrm{KN} / \mathrm{m}^{3}$ at $15 \%$ and after that any increase of $\mathrm{Al}-\mathrm{Khamkha}$ decrease the dry unit weight. On the other hand, the optimum water content of the Jerash cohesive soil was increases with increasing the percentage of Al-Khamkha on the cohesive soil.

\section{Keywords}

\section{Al-Khamkha, Jarash Cohesive Soil, Compaction, Jordan}

\section{Introduction}

In the construction of engineering structures such as highway embankments or earth dams, loose fills are required to be compacted to increase the soil density and improve their strength characteristics [1]. Sometimes, an existing soil deposit may need to be improve in order to enhance its engineering performance [2] Compaction is 
the most common and important method of soil improvement. The densification of soil by the application of mechanical energy is known as compaction it is process by which the soil grains get rearranged more closely, the volume of air voids get reduced, and density of soil increased [3]. Compaction generally leads to an increase in shear strength and helps improve the stability and the bearing capacity of a soil and reduced the settlements [4]. The degree of compaction of a soil is measured in terms of dry unit weight [5]. The soil compaction is accompanied by the remove of soil air, Changes in the soil structure. The soil compaction process is highly influenced by the soil water content [6]-[9].

\section{Methodology}

The aim of this research is to study the effect of using stone cutting slurry waste Al-Khamkha on the dry unit weight and the moisture content of Jerash cohesive soil consequently, qualitative and quantitative analysis of soil compaction spots the light on soil strength characteristic performed for soil compaction to perform the compaction test, sample were taken from eastern area of Jerash city in Jordan and Al-Khamkha was taken from factories hold the generated slurry in open basins in Jerash city .

The compaction test was conducted using "Standard Proctor Test". The soil is mixed with varying amount of $\mathrm{Al}-\mathrm{Khamkha}$ and then compacted in three equal layers.

The moisture unit weight relationship was plotted for each sample tested to obtain the maximum dry unit weight.

\subsection{Standard Proctor Test}

Is the Laboratory Test Used to obtain the maximum dry unit weight of compaction and the optimum moisture content, the soil is compacted unmold that has o volume of $944 \mathrm{~cm}^{3}$.

The soil is mixed with varying amount of wetter and then compacted in 3 quell layers by a hammer that delivers 25 blows to each layer. For each test, the maximum dry unit weigh and the optimum moisture content were determined.

\subsection{Stone Cutting Slurry Waste (Al-Khamkha, Local Name)}

During the processing of cutting stone, the raw stone block is cut either into tiles or slabs of various thickness, using diamond blades water is showered on blades while stone blocks are cut into sheets of varying thickness [10] [11]. To cool blokes and absorb the dust produced during the cutting operation. The amount of the waste water from this operation is very large. It is not recycled as the water is so highly alkaline that, if re-used, at can dim the slabs to be polished [12].

The cooling water is stored in pits until the suspended particles settle (sedimentation tanks) to cool blades.

Then the slurry is collected in trucks and disposed off on the ground and left to dry this water carries larger amount of stone powder, which leads to complex nature of environmental problems such as [13]:

a) Choking of drains in ruing season.

b) Dust nuisance.

c) Find partials of lorry become air borne and cause air pollution.

d) Slurry dumped areas can't support vegetation and remain degraded.

So these waste material needs to be utilized meaningfully in economic way.

However, particular stone cutting slurry waste may have different physical and chemical properties depending on the type of the stone and on the method of generation of waste, in this research stone which used in building as a wall which mostly limestone was used [14] [15].

\section{Analysis and Discussion}

Table 1 it lustrates the physical \& chemical characteristic of slurry samples generated from the stone cutting process for different types of stone [16] [17].

Table 2 and Table 3 illustrate the average of physical and chemical characteristic of Al-Khamkha which used in this research. The result of analysis was compared with other result for Table 2.

It was found that there was a great compositional difference in slurry driver from different cutting processes. 
Table 1. Physical \& chemical characteristic of slurry samples generated from the different type of stone cutting process.

\begin{tabular}{cccc}
\hline Parameter \% & $\begin{array}{c}\text { Torres, et al. (2004) } \\
\text { Granite slurry \% [16] }\end{array}$ & $\begin{array}{c}\text { Turgut, et al. (2007) } \\
\text { Limestone dust \% [10] }\end{array}$ & $\begin{array}{c}\text { Ferreira, et al. (2004) } \\
\text { Granite slurry \% [17] }\end{array}$ \\
\hline $\mathrm{SiO}_{2}$ & 71.65 & 0.26 & 61.2 \\
$\mathrm{CaO}$ & 1.83 & 56.19 & 6.6 \\
$\mathrm{Fe}_{2} \mathrm{O}_{3}$ & 2.86 & 0.3 & 12.4 \\
$\mathrm{Al}_{2} \mathrm{O}_{3}$ & 14.25 & 0.25 & 0.4 \\
$\mathrm{MgO}$ & 0.86 & 0.0 & 0.68 \\
$\mathrm{LOI} \%$ & 0.1 & 42.56 & 0.4 \\
\hline
\end{tabular}

Table 2. Physical properties of powder stone waste.

\begin{tabular}{cccccc}
\hline $\begin{array}{c}\text { Types of } \\
\text { stone waste }\end{array}$ & $\begin{array}{c}\text { Calcium oxide \% } \\
(\mathrm{CaO})\end{array}$ & $\begin{array}{c}\text { Silica \% } \\
\left(\mathrm{SiO}_{2}\right)\end{array}$ & $\begin{array}{c}\text { Aluminum } \\
\text { trioxide \% }\left(\mathrm{Al}_{2} \mathrm{O}_{3}\right)\end{array}$ & $\begin{array}{c}\text { Ferrous oxide \% } \\
\left(\mathrm{Fe}_{2} \mathrm{O}_{3}\right)\end{array}$ & $\begin{array}{c}\text { Magnesium } \\
\text { oxide \% }(\mathrm{MgO})\end{array}$ \\
\hline Lime stone waste & 49.9 & 9.92 & 1.06 & 0.404 & 0.2 \\
\hline
\end{tabular}

Table 3. Chemical properties of powder stone waste [18].

\begin{tabular}{cccc}
\hline Types of stone & Specific gravidity & Bulk density & Color \\
\hline Lime stone & $2.6-2.65$ & $15.7-17.5$ & White/dirty white \\
\hline
\end{tabular}

This variation in the mineralogical and chemical composition of the slurry was attributed to the variation in the type and origin of rocks (15).

To study the effect of Al-Khamkha on the dry unit weight of Jerash cohesive soils, samples were taken from eastern part of Jerash city. The physical properties of the soil are given in Table 4.

The soil is mixed with different amount of Al-Khamkha and compacted using "Standard Proctor Test" the optimum water content and maximum dry unit weight were obtained for trial as it is shown in Figure 1.

Table 5, Figure 2 and Figure 3 show as the amount of Al-Khamkha increase from 0\% to 15\%, the dry unit weight of Jerash cohesive soil increase from $14.4 \mathrm{KN} / \mathrm{m}^{3}$ to $16.5 \mathrm{KN} / \mathrm{m}^{3}$ and the optimum water content also increase from $14 \%$ to $19 \%$. After that as Al-Khamkha increase up to $20 \%$ the dry unit weight of Jerash cohesive soil decrease up to $14.7 \mathrm{KN} / \mathrm{m}^{3}$ and optimum water canted increase to $25 \%$ as the amount of Al-Khamkha increase after that the dry unit weight decrease.

These result provide information about how may manage the compaction and the environment problem of Al-Khamkha to a wise procedure without wasting time, effort energy and money.

Figure 2 shows the relationship between the dry unit weight and the amount of Al-Khamkha.

Figure 3 shows the relationship between the optimum water content and Al-Khamkha.

It's work thy to recall that for certain amount of Al-Khamkha and while increasing the amount of Al-Khamkha up to $15 \%$ the dry unit weight of Jerash cohesive soil increase with small increase of the water content. After that any increase of the amount of Al-Khamkha increase optimum water content and decrease the dry unit weight.

\section{Conclusions}

This investigation focuses on the effect of Al-Khamkha on dry unit weight of Jerash cohesive soil.

Results on Jerash cohesive soil show that as amount of Al-Khamkha mixed with the soil increases, the dry unit weight of Jerash cohesive soil increase up to $15 \%$ of Al-Khamkha and after that any increase of Al-Khamkha decreases the dry unit weight.

The maximum dry density of Jerash cohesive soil was founded at $15 \%$ of Al-Khamkha which may increase the dry density from $14.2 \mathrm{KN} / \mathrm{m}^{3}$ to $16.5 \%$ which intern increase the dry unit weigh of Jerash cohesive soil by $17 \%$. 


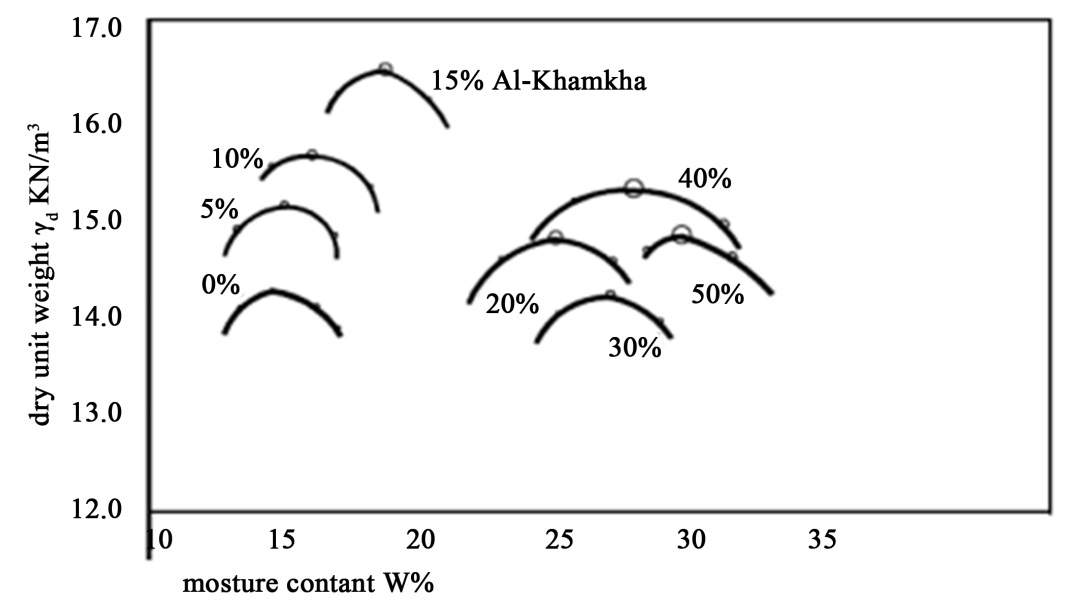

Figure 1. "Standard Proctor Test" the optimum water content and maximum dry unit weight were obtained for trial.

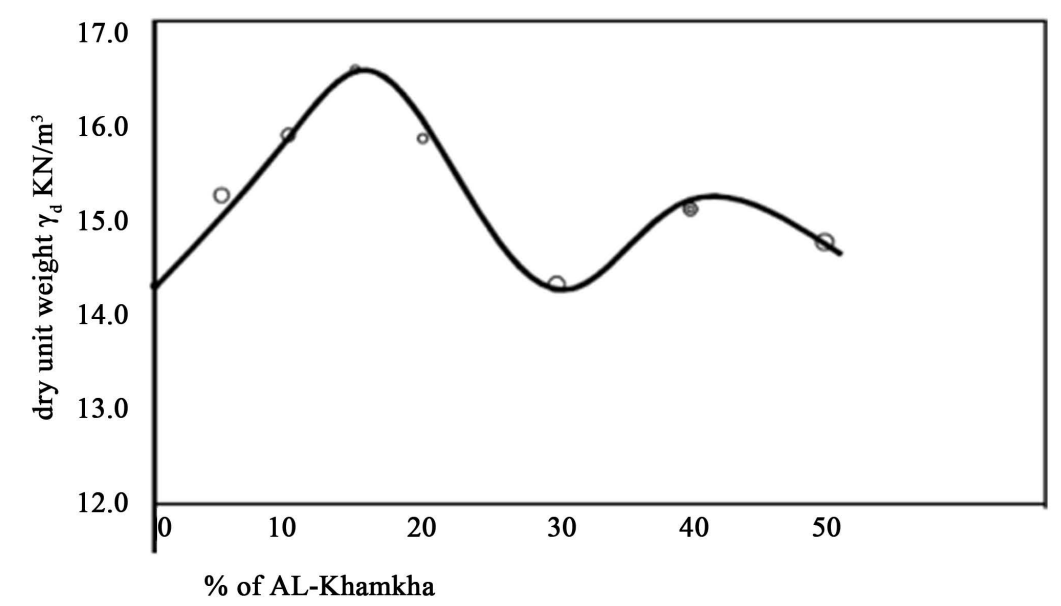

Figure 2. Effect of Al-Khamkha on the compaction characteristic of Jerash cohesive soil.

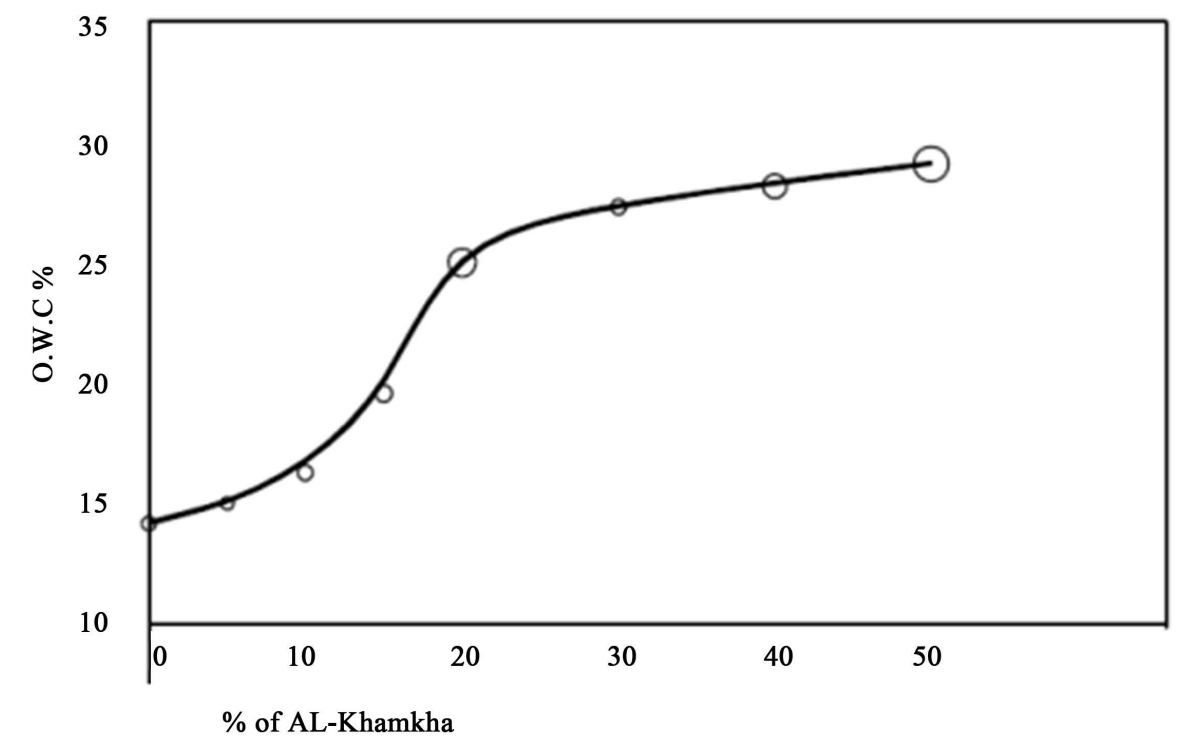

Figure 3. Effect of Al-Khamkha on the compaction characteristic of Jerash cohesive soil. 
Table 4. Physical properties of Jerash cohesive soil.

\begin{tabular}{ccccccc}
\hline Sand & Silt & Clay & Liquid Limit & Plastic Limit & Plasticity Index & Specific Gravity \\
\hline $12 \%$ & $37 \%$ & $51 \%$ & $51 \%$ & $32 \%$ & $19 \%$ & $2.68 \%$ \\
\hline
\end{tabular}

Table 5. The results of the Standard Proctor Test on Jerash cohesive soil with different amount of Al-Khamkha.

\begin{tabular}{ccc}
\hline Percentage of Al-Khamkha \% & Dry unit weight $\left(\mathrm{KN} / \mathrm{m}^{3}\right)$ & Optimum water content \% \\
\hline 0 & 14.4 & 14 \\
5 & 15.2 & 16 \\
10 & 15.67 & 19 \\
15 & 16.5 & 25 \\
20 & 14.7 & 27 \\
30 & 14.3 & 28 \\
40 & 15.1 & 29 \\
\hline
\end{tabular}

Increasing the dry unit weigh of Jerash cohesive soil and intern increasing soil strength characteristics, increasing soil bearing capacity, and creasing soil settlement.

\section{References}

[1] Al-Akhras, N.M., Ababneh, A. and Alaraji, W.A. (2010) Using Burnt Stone Slurry In Mortar Mixes. Construction and Building Materials, 24, 2658-2663. http://dx.doi.org/10.1016/j.conbuildmat.2010.04.058

[2] Batey, T. (2009) Soil Compaction and Soil Management-A Review. Soil Use Manage, 25, 335-345. http://dx.doi.org/10.1111/j.1475-2743.2009.00236.x

[3] Gazi, A., Skevis, G. and Founti, M.A. (2012) Energy Efficiency and Environmental Assessment of a Typical Marble Quarry and Processing Plant. Journal of Cleaner Production, 32, 10-21. http://dx.doi.org/10.1016/j.jclepro.2012.03.007

[4] Fernández-Caliani, J.C. and Barba-Brioso, C. (2010) Metal Immobilization in Hazardous Contaminated Minesoils after Marble Slurry Waste Application. A Field Assessment at the Tharsis Mining District (Spain). Journal of Hazardous Materials, 181, 817-826. http://dx.doi.org/10.1016/j.jhazmat.2010.05.087

[5] Chang, F.-C., Lee, M.-Y., Lo, S.-L. and Lin, J.-D. (2010) Artificial Aggregate Made from Waste Stone Sludge and Waste Silt. Journal of Environmental Management, 91, 2289-2294. http://dx.doi.org/10.1016/j.jenvman.2010.06.011

[6] Al-Joulani, N. (2014) Utilization of Stone Slurry Powder in Production of Artificial Stones. Research Journal in Engineering and Applied Sciences, 3, 245-249.

[7] Hamza, M. and Anderson, W. (2005) Soil Compaction in Cropping Systems. A Review of The nature, Causes and Possible Solutions. Soil \& Tillage Research, 82, 121-145. http://dx.doi.org/10.1016/j.still.2004.08.009

[8] Al-Joulani, N. and Salah, N. (2014) The Stone Slurry in Palestine from Environmental Burden to Economic Opportunities-Feasibility Analysis. Journal of Environmental Protection, 5, 1075-1090.

[9] Patel, A.N. and Pitroda, J. (2013) Stone Waste in India for Concrete with Value Creation Opportunities. International Journal of Latest Trends in Engineering and Technology, 2, 113-120.

[10] Turgut, P. and Algin, H.M. (2007) Limestone Dust and Wood Sawdust as Brick Material. Building and Environment Journal, 42, 3399-3403. http://dx.doi.org/10.1016/j.buildenv.2006.08.012

[11] Ammary, B. (2007) Clean Cutting Stone Industry. International Journal of Environment and Waste Management, 1, 106-112. http://dx.doi.org/10.1504/IJEWM.2007.013627

[12] Almeida, N., Branco, F. and Santos, J.R. (2007) Recycling of Stone Slurry in Industrial Activities: Application to Concrete Mixtures. Building and Environment, 42, 810-819. http://dx.doi.org/10.1016/j.buildenv.2005.09.018

[13] APHA (1998) Standard Methods for the Examination of Water and Wastewater. 20th Edition, American Public Health Association, Washington DC. 
[14] Colombo, A., Tunesi, A., Barberini, V., Galimberti, L. and Cavallo, A. (2008) Chemical and Mineralogical Characterization of Cutting Process Sludge, Exploitation of Sludge from Stone Working Synthesis of the Research. http://www.aigt.ch/ download/ rapporto_INTERREGen.pdf

[15] Arslan E.I., Aslan, S., Ipek, U., Altun, S. and Yaziciolu, S. (2005) Physico-Chemical Treatment of Marble Processing Wastewater and the Recycling of Its Sludge. Waste Management \& Research, 23, 550-559. http://dx.doi.org/10.1177/0734242X05059668

[16] Torres, P., Fernandes, H.R., Agathopoulos, S., Tulyaganov, D.U. and Ferreira, J.M.F. (2004) Incorporation of Granite Cutting Sludge in Industrial Porcelain Tile Formulations. Journal of the European Ceramic Society, 24, 3177-3185. http://dx.doi.org/10.1016/j.jeurceramsoc.2003.10.039

[17] Ferreira, J.M.F., Torres, P.M.C., Silva, M.S. and Labrincha J.A. (2004) Recycling of Granite Sludge in Brick-Type and Floor Tile-Type Ceramic Formulation. Journal of the European Ceramic Society, 24, 3177-3185.

[18] Alzboon, K.K. and Mahasneh, K.N. (2009) Effect of Using Stone Cutting Waste on the Compression Strength and Slump Characteristics of Concrete. International Journal of Environmental Science and Engineering, 1, 167-172. 